\title{
Analysis of Springback Behavior in Steel and Aluminum Sheets Using FEM
}

\author{
Ali Jumah Aday \\ Department of Mechanical Engineering, University of Babylon, Babylon, Iraq
}

Corresponding Author Email: 1aliengineer@gmail.com

https://doi.org/10.18280/acsm.430205

Received: 3 January 2019

Accepted: 19 March 2019

\section{Keywords:}

finite element analysis, sheet metal, springback, die profile radius

\begin{abstract}
In this paper, the phenomenon of springback and how to reduce this phenomenon were studied experimentally and theoretically. To simulate springback effect and analyze the results theoretically, a special program (finite elements (ANSYS 18.1)) has been used. The simulation of the bending sheet metal has been performed by using a rectangular plate of aluminum alloy (3105) and low carbon steel (1020) with three different thickness $(1,1.5,2)$ $\mathrm{mm}$ using die profile radius $(50) \mathrm{mm}$. These parameters have been used to study the effect of type and thickness of metal used with die profile radius on the amount spring back and residual stresses after removing the load. The results obtained for aluminum (3105) and low carbon steel (1020) revealing that, the amount of springback is decreasing with increase thickness of the plate. In addition, the results showed that the amount of springback for aluminum plates is higher than low carbon steel in all cases. The experimental results is in a good agreement with numerical results .
\end{abstract}

\section{INTRODUCTION}

Throughout Springback phenomenon occurs in sheet metal forming process (SMF), because of the nature of the material elasticity. Thus, springback cannot be eliminated but can be minimized or compensated in the die. Therefore, the handling of springback is very important in the design of the die to produce a product with a high accuracy dimension [1]. Various methods are used to reduce the springback. Lee [2] studied the bi-directional springback of drawn sheet metal parts using the modified U-draw bending process. Chung, et al. [3] studied how to develop the prediction capability of spring back in automotive sheet forming processes, the combined isotropickinematic hardening law based on the modified Chaboche model was formulated to account for the bauschinger effect and the transient behavior. Zang, et al. [4] submitted a study to improve the prediction capability of spring-back in the computational analysis of sheet metal forming processes, a stress-strain constitutive formulation of non-linear combined hardening rule has been proposed their study according to nonlinear kinematic hardening theory of Lemaitre and Chaboche and Hill's 1948 anisotropic yielding function. Kim and Koc [5] carried numerical investigations on springback characteristics of aluminum sheet metal alloys in warm forming conditions. Da-xin, et al. [6], studied through extensive experiments and finite element method (FEM) analysis spring back in bending metal tube. Paik, et al. [7] developed on advanced computer aided manufacture (CAM) system called the changeable die system (CDS) that applied to the cold-forming technique to produce curved metal plates with complex, three-dimensional geometry. Thipprakmas and Phanitwong [8] studied process parameter design of springback and spring-go in V-bending process using Taguchi technique. Sharad and Nandedkar [9] studied the change of some various parameters affecting springback such as the ratio of die radius to sheet thickness, sheet thickness, blank holder force, the coefficient of friction etc. Leu [10] proposed a simplified approach to distinguish between spring-back and spring-go in free U-die bending process of SPFC 440 sheets. $\mathrm{Li}$, et al. [11] studied Effect of machining-induced residual stresses on springback of creep age formed (CAF) AA2050 plates with asymmetric creep-ageing behavior has been investigated experimentally and numerically.

In this study, analytical and experimental studies were conducted to know the influence of different type metal and thickness of sheet metal with radius of die profile on springback. The results of experimental were compared with the numerical simulation results to check the proposed model.

\section{EXPERIMENTAL PROCEDURE}

The experimental work includes the manufacturing of sheet bending rig. has been executed to measure springback of the workpiece after bending operation for (aluminum alloy and steel) sheets. In this study, low carbon steel (1020) and AA3105 specimenes of length $250 \mathrm{~mm}$ and width $30 \mathrm{~mm}$ with different thicknesses such as $1 \mathrm{~mm}, 1.5 \mathrm{~mm}, 2 \mathrm{~mm}$ is considered. The properties of ow carbon steel (1020) and AA3105 measured in Table 1.

Table 1. The mechanical properties of Aluminum (3105) and Low carbon steel (1020)

\begin{tabular}{cccc}
\hline Metal & $\begin{array}{c}\text { Density(p) } \\
\mathbf{g m} / \mathbf{c m}^{\mathbf{3}}\end{array}$ & $\begin{array}{c}\text { Poisson's } \\
\text { ratio(v) }\end{array}$ & $\begin{array}{c}\text { Modulus of } \\
\text { elasticity (E) } \\
\text { MPa }\end{array}$ \\
\hline AA3105 & 2.75 & 0.33 & 69000 \\
\hline $\begin{array}{c}\text { Low carbon } \\
\text { steel 1020 }\end{array}$ & 7.80 & 0.3 & 204000 \\
\hline
\end{tabular}


Experiment set-up is composed of arm, radius die profile $(\mathrm{R}=50 \mathrm{~mm})$ and load cell to measure applied force which is shown in Figure 1. The springback occurs after removing the applied force on the blank. Dimensions of the bending die are same as the ones used in finite element analysis.

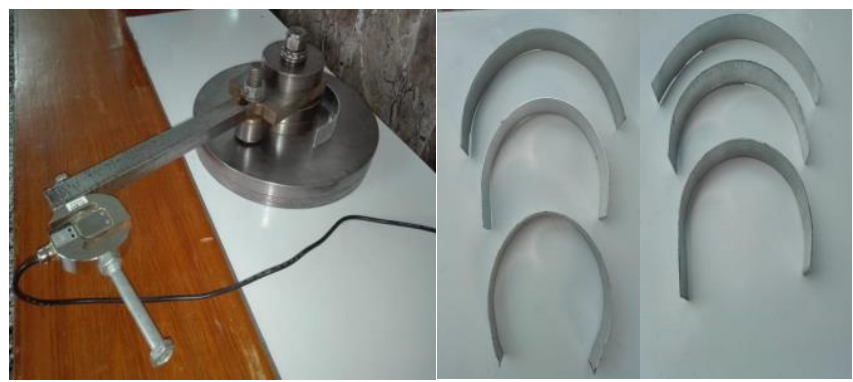

Figure 1. Bending die and final product with different type of metal and thicknesses

\section{FEA OF BENDING OPERATION}

In this work, bending operation of low carbon steel (1020) and AA3105 material has been analyzed by FEM software package, (ANSYS 18.1). The results of springback, max of von mises stresses, directional deformation in coordinate axis. The input data are the material properties, boundary conditions and applied load. The low carbon steel (1020) and AA3105 sheets used in this work. FE model used in springback simulations is composed of a rigid arm with roller and die and a deformable sheet metal. The rigid arm moves to bend the workpiece. Model (rig) and mesh of model shown in Figure 2.
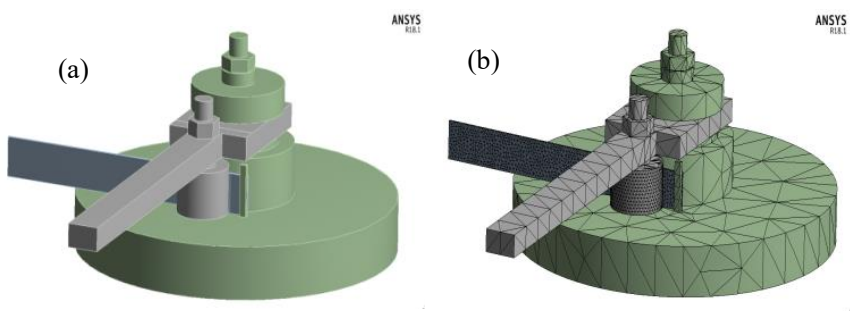

Figure 2. (a) Model(rig), (b) Mesh of model

\section{ANSYS RESULTS}

Results such as maximum von-mises stresses and directional deformation in $\mathrm{X}$-axis(springback) for aluminum alloy (3105) and low carbon steel are obtained.

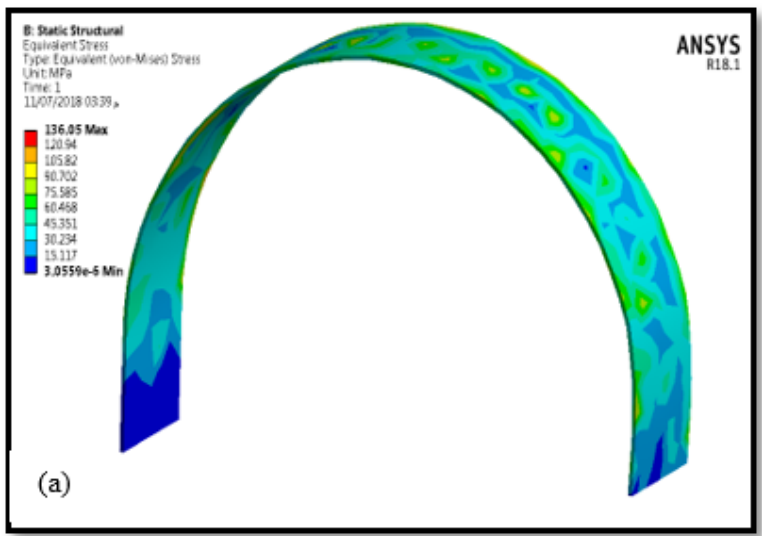

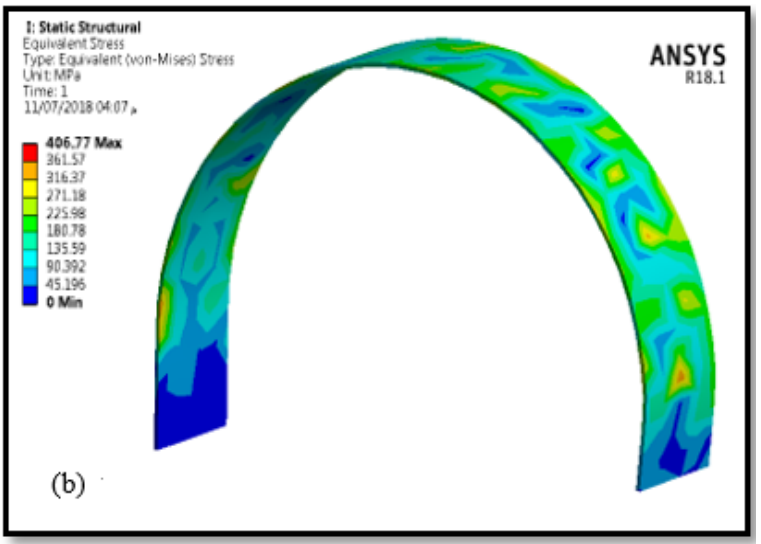

Figure 3. (a)Von misses stress of (aluminum alloy), (b) Von misses stress of (steel) (thickness $(t)=1 \mathrm{~mm})$
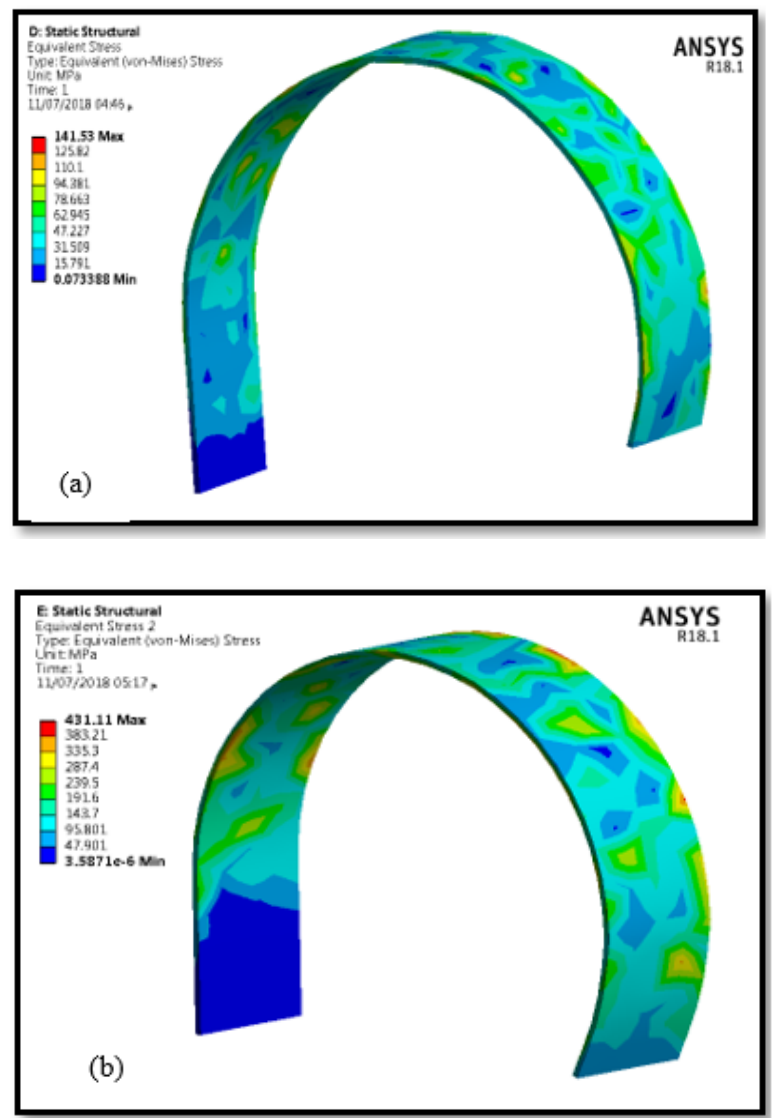

Figure 4. (a)Von misses stress of (aluminum alloy), (b) Von misses stress of (steel) (thickness $(\mathrm{t})=1.5 \mathrm{~mm})$

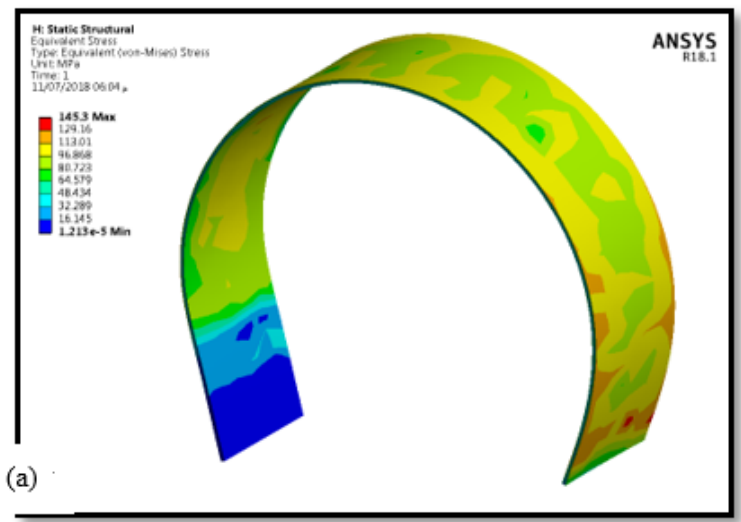




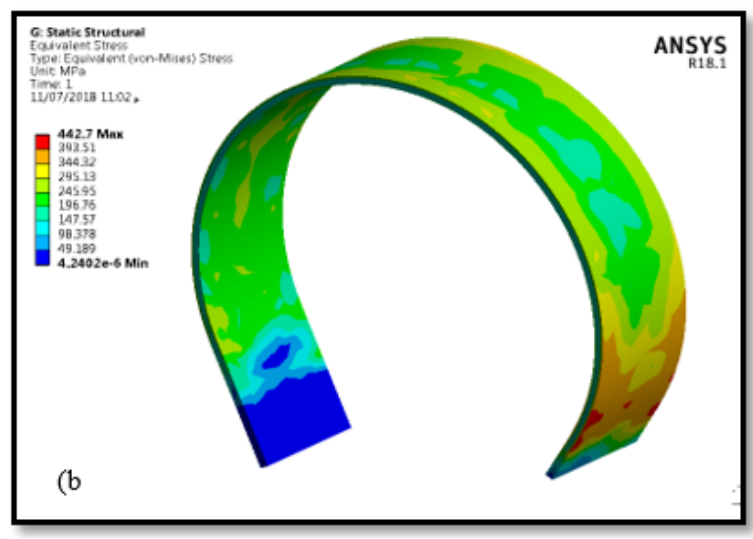

Figure 5. (a) Von misses stress of (aluminum alloy), (b) Von misses stress of (steel) (thickness $(t)=2 \mathrm{~mm})$
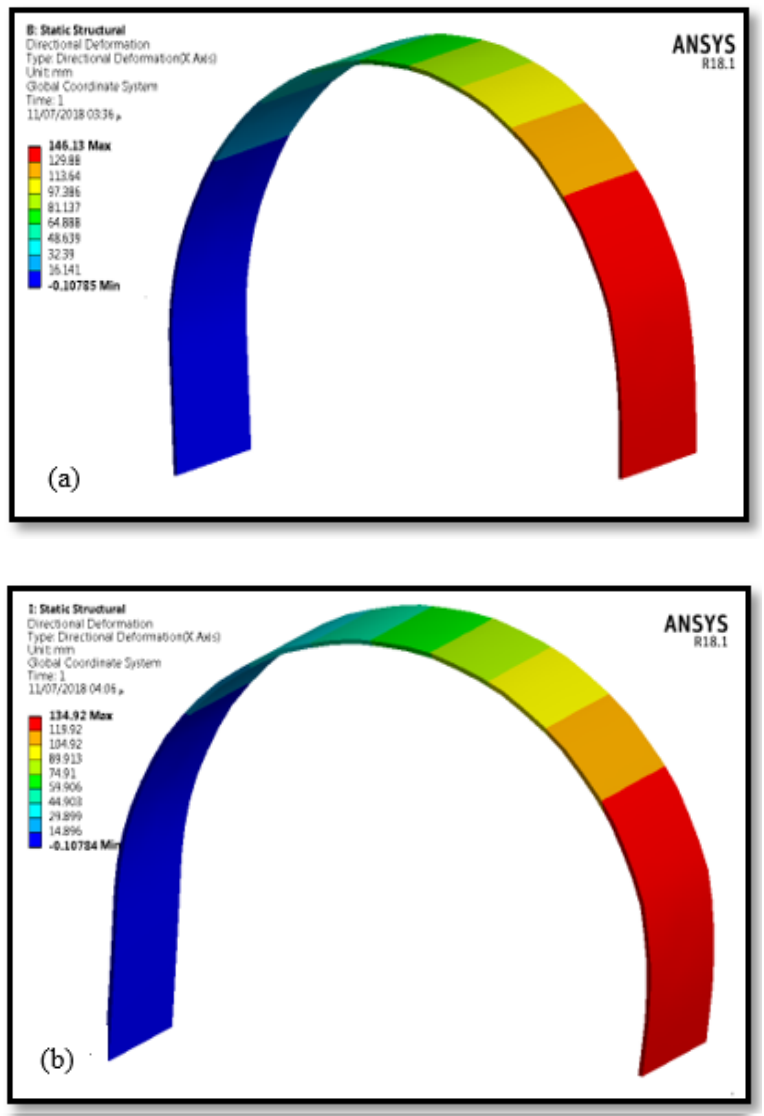

Figure 6. (a) Directional deformation of aluminum alloy, (b) Directional deformation of steel (thickness $=1 \mathrm{~mm}$ )

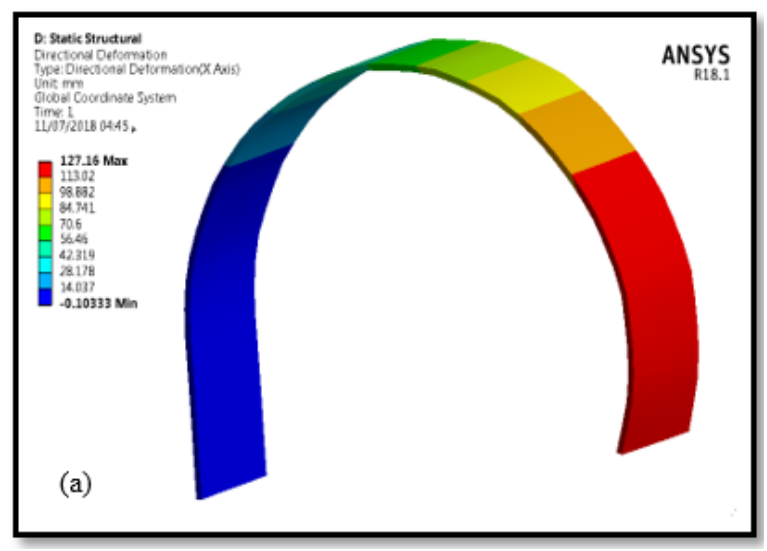

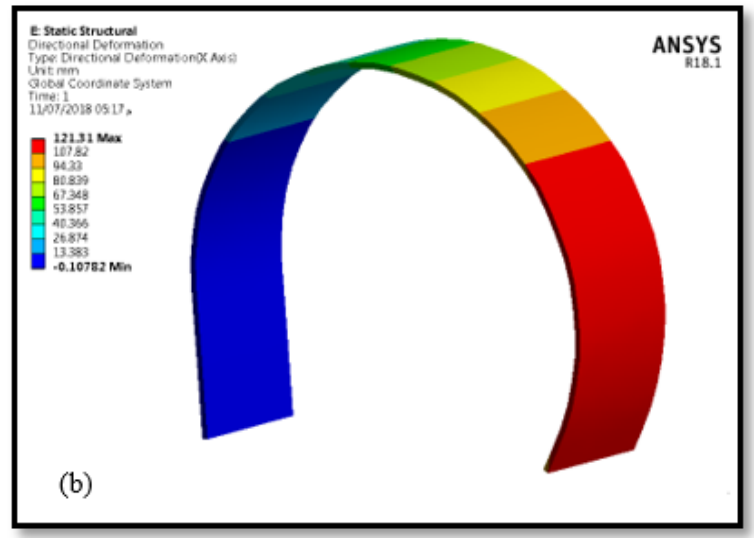

Figure 7. (a) Directional deformation of aluminum alloy, (b) Directional deformation of steel (thickness $=1.5 \mathrm{~mm}$ )
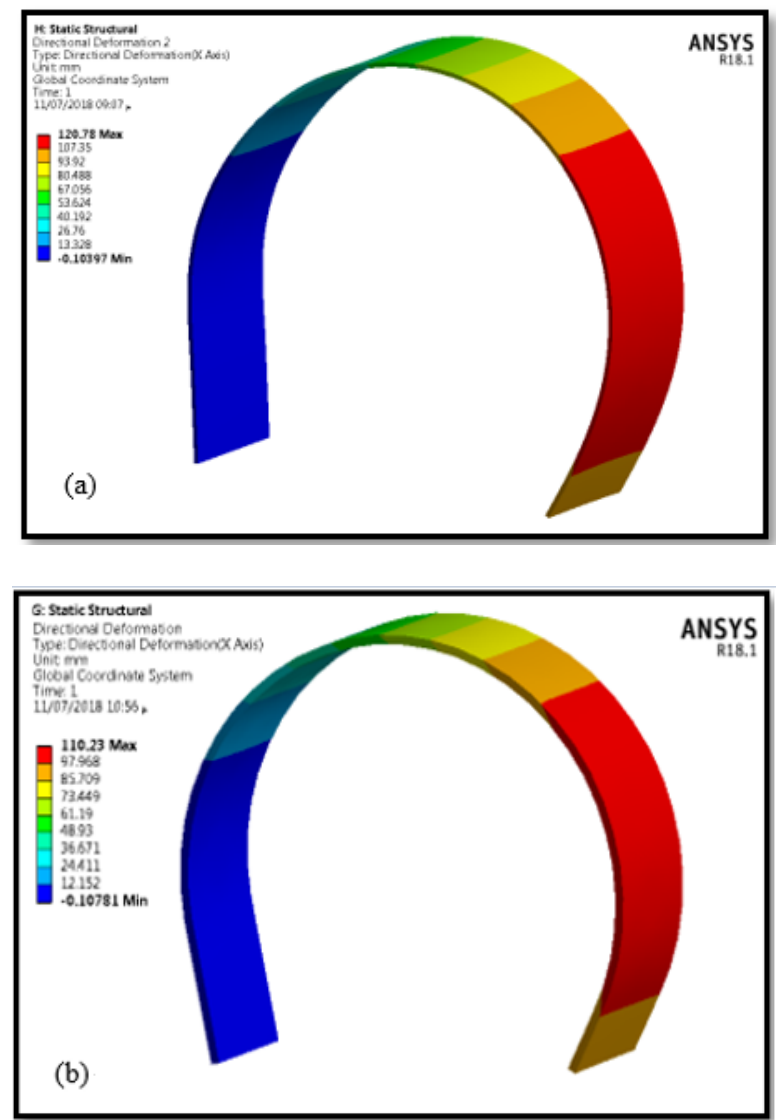

Figure 8. (a) Directional deformation of aluminum alloy, (b) Directional deformation of steel (thickness $=2 \mathrm{~mm}$ )

From Figure 3 to Figure 5, the maximum of von-mises stress at sheet thickness $(2 \mathrm{~mm})$ with die profile radius $\mathrm{R}=50 \mathrm{~mm}$ for both (aluminum and steel). Where the highest Von Mises stress for aluminum sheet is $(145.3 \mathrm{Mpa})$ and the highest Von Mises stress for steel sheet is $(442.7 \mathrm{Mpa})$.

From Figure 6 to Figure 8, the maximum directional deformation at sheet thickness $(1 \mathrm{~mm})$ with die profile radius $\mathrm{R}=50 \mathrm{~mm}$ for both (aluminum and steel). The high springback for aluminum is $146.13 \mathrm{~mm}$ and the high springback for steel is $134.92 \mathrm{~mm}$. After all the numerical analysis, springback is measured for each case and tabulated as below. 
Table 2. Variation of the springback with different thickness for (aluminum and steel)

\begin{tabular}{ccc}
\hline $\begin{array}{c}\text { Thickness } \\
\text { mm }\end{array}$ & $\begin{array}{c}\text { Springback } \\
\text { for aluminum(mm) }\end{array}$ & $\begin{array}{c}\text { Springback } \\
\text { for steel }(\mathbf{m m})\end{array}$ \\
\hline 1 & 146.13 & 134.92 \\
\hline 1.5 & 127.16 & 121.31 \\
\hline 2 & 120.78 & 110.23 \\
\hline
\end{tabular}

\section{RESULTS AND DISCUSSIONS}

The results from the FEA by ANSYS and experimental values of springback are listed and compared below.

Table 3. Comparison of experimental and FEA values of springback for low carbon steel (1020)

\begin{tabular}{cccc}
\hline $\begin{array}{c}\text { Thickness } \\
\text { mm }\end{array}$ & $\begin{array}{c}\text { Experiment spring } \\
\text { back effect }(\mathbf{m m})\end{array}$ & $\begin{array}{c}\text { FEA springback } \\
\text { effect }(\mathbf{m m})\end{array}$ & $\begin{array}{c}\text { Error } \\
\text { \% }\end{array}$ \\
\hline 1 & 136 & 134.92 & 0.8 \\
\hline 1.5 & 126 & 121.31 & 3.8 \\
\hline 2 & 115 & 110.23 & 4.3 \\
\hline
\end{tabular}

Table 4. Comparison of experimental and FEA values of springback for aluminum alloy (AA3105)

\begin{tabular}{cccc}
\hline $\begin{array}{c}\text { Thickness } \\
\text { mm }\end{array}$ & $\begin{array}{c}\text { Experiment spring } \\
\text { back effect }(\mathbf{m m})\end{array}$ & $\begin{array}{c}\text { FEA springback } \\
\text { effect }(\mathbf{m m})\end{array}$ & $\begin{array}{c}\text { Error } \\
\mathbf{\%}\end{array}$ \\
\hline 1 & 149 & 146.13 & 2.26 \\
\hline 1.5 & 132 & 127.16 & 3.80 \\
\hline 2 & 125 & 120.78 & 3.49 \\
\hline
\end{tabular}

Table 3 and Table 4 shows the variation in the numerical and experimental values of springback with the different thickness. As the thickness of the sheet metal (AA3105, LCS) increases the springback decreases.

\section{CONCLUSIONS}

In this study, springback effect is evaluated under different type of metal and thickness sheets. Also FEA study has conjointly been carried out the assistance of ANSYS. Experimental study on springback has been done by considering low carbon steel (1020) and AA3105 of different thicknesses like $1 \mathrm{~mm}, 1.5 \mathrm{~mm}, 2 \mathrm{~mm}$. It has been observed that as the effect of springback of aluminum alloy (3105) in the different thickness is greater than steel (1020) sheet. Springback is affected by thickness change, when the thickness of sheet metal is increased the spring back is decreased. The von-mises stresses are observed to increase with an increase in sheet thickness. Springback is affected by a yield stress and modulus elasticity of the metal.

\section{REFERENCES}

[1] Anggono, A.D., Siswanto, W.A., Omar, B. (2012). Algorithm development and application of spring back compensation for sheet metal forming. Research Journal of Applied Sciences. Engineering and Technology, 4(14): 2036-2045.

[2] Lee, S.W. (2005). A study on the bi-directional springback of sheet metal stamping. Journal of Materials Processing Technology, 167(1): 33-40. https://doi.org/10.1016/j.jmatprotec.2004.09.083

[3] Chung, K., Lee, M.G., Kim, D., Kim, C., Wenner, M.L., Barlat, F. (2005). Spring-back evaluation of automotive sheets based on isotropic-kinematic hardening laws and non-quadratic anisotropic yield functions: Part I: theory and formulation. International Journal of Plasticity, 21(5): 861-882. https://doi.org/10.1016/j.ijplas.2004.05.016

[4] Zang, S., Liang, J., Guo, C. (2007). A constitutive model for spring-back prediction in which the change of Young's modulus with plastic deformation is considered. International Journal of Machine Tools and Manufacture, 47(11): $1791-1797$ https://doi.org/10.1016/j.ijmachtools.2007.01.003

[5] Kim, H.S., Koç, M. (2008). Numerical investigations on springback characteristics of aluminum sheet metal alloys in warm forming conditions. Journal of Materials Processing Technology, 204(1-3): 370-383. https://doi.org/10.1016/j.jmatprotec.2007.11.059

[6] Da-Xin, E., He, H.H., Liu, X.Y., Ning, R.X. (2009). Spring-back deformation in tube bending. International Journal of Minerals. Metallurgy and Materials, 16(2): 177-183. https://doi.org/10.1016/S1674-4799(09)600303

[7] Paik, J.K., Kim, J.H., Kim, B.J., Tak, C.H. (2010). Analysis of spring-back behavior in the cold-forming process of three-dimensionally curved metal plates. in ASME 2010 29th International Conference on Ocean, Offshore and Arctic Engineering, https://doi.org/10.1115/OMAE2010-20759

[8] Thipprakmas, S., Phanitwong, W. (2011). Process parameter design of springback and spring-go in $\mathrm{V}$ bending process using Taguchi technique. Materials \& Design, 32(8-9): 4430-4436. https://doi.org/10.1016/j.matdes.2011.03.069

[9] Sharad, G., Nandedkar, V., (2014). Springback in sheet metal u bending-FEA and neural network approach. Procedia Materials Science, 6: 835-839. https://doi.org/10.1016/j.mspro.2014.07.100.

[10] Leu, D.K. (2016). A simplified approach for distinguishing between spring-back and spring-go in free U-die bending process of SPFC 440 sheets. Materials \& Design, 94: 314-321. https://doi.org/10.1016/j.matdes.2016.01.020 350401.

[11] Li, Y., Shi, Z., Lin, J., Yang, Y.L., Saillard, P., Said, R. (2018). Effect of machining-induced residual stress on springback of creep age formed AA2050 plates with asymmetric creep-ageing behaviour. International Journal of Machine Tools and Manufacture, 132: 113122. https://doi.org/10.1016/j.ijmachtools.2018.05.003. 